\title{
Transgenic Plants Expressing Geminivirus Movement Proteins: Abnormal Phenotypes and Delayed Infection by Tomato mottle virus in Transgenic Tomatoes Expressing the Bean dwarf mosaic virus BV1 or BC1 Proteins
}

\author{
Yu-Ming Hou, ${ }^{1}$ Rick Sanders, ${ }^{2}$ Virgina M. Ursin, ${ }^{2}$ and Robert L. Gilbertson ${ }^{1}$ \\ ${ }^{1}$ Department of Plant Pathology, University of California, Davis 95616, U.S.A.; ${ }^{2}$ Calgene LLC., Davis, CA \\ 95616, U.S.A. \\ Accepted 15 November 1999.
}

\begin{abstract}
Transgenic tomato plants expressing wild-type or mutated BV1 or BC1 movement proteins from Bean dwarf mosaic virus (BDMV) were generated and examined for phenotypic effects and resistance to Tomato mottle virus (ToMoV). Fewer transgenic plants were recovered with the wild-type or mutated $B C 1$ genes, compared with the wild-type or mutated $B V 1$ genes. Transgenic tomato plants expressing the wild-type or mutated BV1 proteins appeared normal. Interestingly, although BDMV induces only a symptomless infection in tomato (i.e., BDMV is not well adapted to tomato), transgenic tomato plants expressing the BDMV BC1 protein showed a viral diseaselike phenotype (i.e., stunted growth, and leaf mottling, curling, and distortion). This suggests that the symptomless phenotype of BDMV in tomato is not due to a hostspecific defect in the $\mathrm{BC} 1$ protein. One transgenic line expressing the $B C 1$ gene did not show the viral disease-like phenotype. This was associated with a deletion in the $3^{\prime}$ region of the gene, which resulted in expression of a truncated $\mathrm{BC} 1$ protein. Several $\mathbf{R}_{0}$ plants, expressing either wild-type or mutated BV1 or BC1 proteins, showed a significant delay in ToMoV infection, compared with nontransformed plants. $R_{1}$ progeny plants also showed a significant delay in ToMoV infection, but this delay was less than that in the $R_{0}$ parents. These results also demonstrate that expression of viral movement proteins, in transgenic plants, can have deleterious effects on various aspects of plant development.
\end{abstract}

Whitefly-transmitted geminiviruses (family Geminiviridae, genus Begomovirus) are economically important plant pathogens that cause severe diseases in many crop plants (Bock 1982; Brown 1990; Polston and Anderson 1997). Although

Corresponding author: Robert L. Gilbertson; Department of Plant Pathology, University of California, Davis 95616, U.S.A.; Telephone: 530752-3163; Fax: 530-752-5674; E-mail: rlgilbertson@ucdavis.edu

Current address of Yu-Ming Hou: Novartis Agricultural Discovery Institute, Inc., 3115 Merryfield Row, San Diego, CA 92121, U.S.A. much has been learned about geminivirus pathogenesis, management of most geminivirus-induced diseases remains problematic, often relying on suppression of whitefly populations by application of insecticides. Pathogen-derived resistance (Sanford and Johnston 1985) could provide an efficient method for disease management. Several viral sequences have been evaluated for their potential to confer resistance to begomoviruses when expressed in transgenic plants, including defective interfering DNA components (Stanley et al. 1990), the replication-associated protein (Day et al. 1991; Bejarano and Lichtenstein 1994; Hong and Stanley 1996; Noris et al. 1996; Bendahmane and Gronenborn 1997; Sangare et al. 1999), the BC1 movement protein (MP) (Duan et al. 1997b), and the coat protein (CP; Kunik et al. 1994). All of these approaches have generated transgenic plants that exhibited delayed and/or attenuated symptoms when inoculated with the geminivirus from which the transgene was derived. However, with the exception of CP from Tomato yellow leaf curl virus expressed in tomato plants (Kunik et al. 1994), these pathogen-derived resistance strategies were evaluated in experimental hosts (e.g., Nicotiana benthamiana or N. tabacum) rather than in natural (economically important) hosts of these viruses. Hence, the practical utility of these transgenes for protecting crop plants from geminivirus infection remains to be established. Furthermore, because more than one geminivirus may infect a given crop plant and/or some diseases are caused by a complex of geminiviruses (Sharp et al. 1999), it is desirable to develop a broad-spectrum resistance strategy.

Most begomoviruses possess a bipartite genome that is composed of two approximately 2.6-kb DNA components referred to as DNA-A and DNA-B. DNA-A encodes proteins involved in replication, gene expression, and encapsidation, whereas DNA-B encodes proteins involved in movement, symptom development, and host range (reviewed in Timmermans et al. 1994). DNA-B encodes two proteins, BV1 and $\mathrm{BC} 1$, that are required for, and function cooperatively in, cellto-cell and long-distance movement. Microinjection of Escherichia coli-expressed BV1 and BC1 MPs of Bean dwarf mosaic virus (BDMV) has established that the BV1 MP mediates the export of viral DNA from the nucleus to cytoplasm, 
whereas the BC1 MP increases the size exclusion limit of plasmodesmata and mediates the cell-to-cell movement of viral DNA (Noueiry et al. 1994). Consistent with these functions, the BDMV BV1 and BC1 MPs bind single- and doublestranded DNA in a size- and form-specific manner (Rojas et al. 1998). Single amino acid substitutions of conserved amino acids in BDMV BV1 (BV1-K95E, lysine at position 95 replaced by glutamic acid) and $\mathrm{BC} 1$ (BC1-D78N, aspartic acid at position 78 replaced by asparagine) abolished transport functions (Noueiry et al. 1994), but not DNA binding properties (Noueiry 1995). Therefore, it was hypothesized that these mutated MPs, expressed in transgenic plants, may act as dominant negative mutants by outcompeting the virusencoded, wild-type MPs. The end result of such competition would be resistance to viral infection due to interference with virus movement. Moreover, because the MP genes of bipartite geminiviruses are highly conserved (Timmermans et al. 1994), this approach might confer broad-spectrum resistance.

The expression of mutated or nonfunctional MPs in transgenic plants has been tested as a resistance strategy for plant RNA viruses (Malyshenko et al. 1993; Beck et al. 1994; Cooper et al. 1995; Tacke et al. 1996; Seppanen et al. 1997; Ares et al. 1998). In general, these transgenic plants showed some level of resistance to infection by the virus from which the transgene was derived. In some cases, these plants also showed resistance to other viruses, including some from related groups having MP gene similarity (Beck et al. 1994; Seppanen et al. 1997) and/or some from groups with no apparent MP gene similarity (Malyshenko et al. 1993; Cooper et al. 1995; Tacke et al. 1996; Ares et al. 1998). This approach has been proposed for bipartite geminiviruses (von Arnim and Stanley 1992), and was successfully demonstrated in an experimental host system (Duan et al. 1997b). However, the efficacy of this strategy has not been evaluated in a crop plant against infection by a geminivirus that is well adapted to that host (i.e., an economically important virus that infects the crop plant in nature).

To determine whether nonfunctional geminiviral MPs can act as dominant negative mutants and provide broad-spectrum geminivirus resistance in a crop plant, transgenic tomato plants with the BDMV $B V 1, B V 1-K 95 E, B C 1$, or $B C 1-D 78 N$ genes were generated and challenged with Tomato mottle virus (ToMoV). BDMV and ToMoV are closely related, but BDMV is adapted to common bean, whereas ToMoV is adapted to tomato (Gilbertson et al. 1993; Hou et al. 1998). The effects of expression of the BDMV MPs in transgenic tomato plants are discussed in terms of (i) plant development and (ii) resistance to ToMoV infection.

\section{RESULTS}

\section{Transformation of tomato plants.}

The $B V 1, B V 1-K 95 E, B C 1$, or $B C 1-D 78 N$ genes of BDMV (Fig. 1) were individually introduced into tomato cotyledons by Agrobacterium tumefaciens-mediated transformation. The regeneration rate of shoots was considerably lower for the $B V 1, B C 1$, and $B C 1-D 78 N$ genes than for the $B V 1-K 95 E$ gene (Table 1). Moreover, the frequencies for the BDMV MPs were much lower than those obtained with nontransformed tomato cotyledons or those previously obtained for a variety of other (mostly nonviral) genes introduced into tomato plants (V. Ur- sin and R. Sanders, unpublished data). From three independent transformation experiments, 23 BV1, 38 BV1-K95E, 16 $\mathrm{BC} 1$, and $10 \mathrm{BC} 1-\mathrm{D} 78 \mathrm{~N} \mathrm{R} \mathrm{R}_{0}$ plants (primary transformants) were generated (Table 1). Many of the plants generated from primary transformation events, particularly those transformed with the $B C l$ gene, had stunted growth and small, chlorotic, and crumpled leaves. In some transformants, meristems failed to develop. Abnormal phenotypes were not observed in plants regenerated from nontransformed tomato cotyledons. The reduced regeneration frequencies and abnormal phenotypes suggested a deleterious effect of the BDMV MPs on growth and/or development of transformed tomato tissues.

\section{Characterization of $\mathbf{R}_{\mathbf{0}}$ plants.}

Southern blot hybridization analysis of total genomic DNA from $\mathrm{R}_{0}$ plants (primary transformants) with $\mathrm{BC} 1$ - or BV1specific probes revealed that at least one transgene copy was present in 21 of $23 \mathrm{BV} 1$, all $38 \mathrm{BV} 1-\mathrm{K} 95 \mathrm{E}, 9$ of $16 \mathrm{BC} 1$, and 6 of 10 BC1-D78N plants (Fig. 2 and Table 1). To determine whether the plants lacking the MP genes represented nontransformed escapes (i.e., no T-DNA integration) or contained an altered T-DNA, Southern blot hybridization analysis was performed with a probe specific for the neomycin phosphotransferase II (NPT II) gene. Two BV1, 2 BC1, and 2 BC1-D78N plants lacked the NPT II and BDMV MP genes (i.e., did not have an integrated T-DNA) and, therefore, were escapes. One BV1-K95E plant contained the MP gene but not the NPT II gene, whereas $5 \mathrm{BC} 1$ and $2 \mathrm{BC} 1-\mathrm{D} 78 \mathrm{~N}$ plants contained the NPT II gene but not the MP genes. The lack of the BDMV MP transgene in these plants may be due to incomplete T-DNA integration or deletion of the MP genes in the integrated TDNA during transformation and/or regeneration. Because the MP gene was closer than the NPT II gene to the right border of the T-DNA (the initiation site for T-DNA integration) (Fig. 1), the MP genes were presumably integrated into the plant genome together with the NPT II gene. Therefore, it is most likely that a deletion had occurred in the BC1/BC1-D78N sequences of the T-DNA.

Transgene expression was examined by immunoblot analysis with antiserum raised against the BDMV BV1 or BC1 proteins, and by Northern (RNA) blot hybridization analysis with BV1- or BC1-specific probes. Immunoblot analysis revealed a protein of approximately $31 \mathrm{kDa}$ in $17 \mathrm{BV} 1$ plants and 26 BV1-K95E plants, and a protein of approximately 34 $\mathrm{kDa}$ in $2 \mathrm{BC} 1$ plants and $4 \mathrm{BC} 1-\mathrm{D} 78 \mathrm{~N}$ plants (Fig. 3 and Table 1). In one $\mathrm{BC} 1$ plant, $\mathrm{BC} 1-49$, a truncated $\mathrm{BC} 1$ protein of approximately $31 \mathrm{kDa}$ was detected (Fig. 3B). No similarsized proteins were detected in nontransformed tomato plants.

Northern blot hybridization analysis revealed an approximately 1.3-kb RNA in BV1 and BV1-K95E plants, and an approximately 1.45-kb RNA in BC1 and BC1-D78N plants (Fig. 4). Several RNAs, ranging from approximately $1.3 \mathrm{~kb}$ to approximately $5 \mathrm{~kb}$, were detected in the $\mathrm{BC} 1-49$ plant. The truncated $31-\mathrm{kDa} \mathrm{BC} 1$ protein detected in this plant was presumably translated from the predominant 1.3-kb transcript (Fig. 4B). Levels of transgene expression varied among plants but, in general, levels of transgene-encoded proteins were proportional to levels of transgene transcript detected (data not shown).

The two transgenic plants expressing the 34-kDa BDMV $\mathrm{BC} 1$ protein showed an abnormal phenotype, including stunted growth and leaf mottling and distortion (Fig. 5A). This 


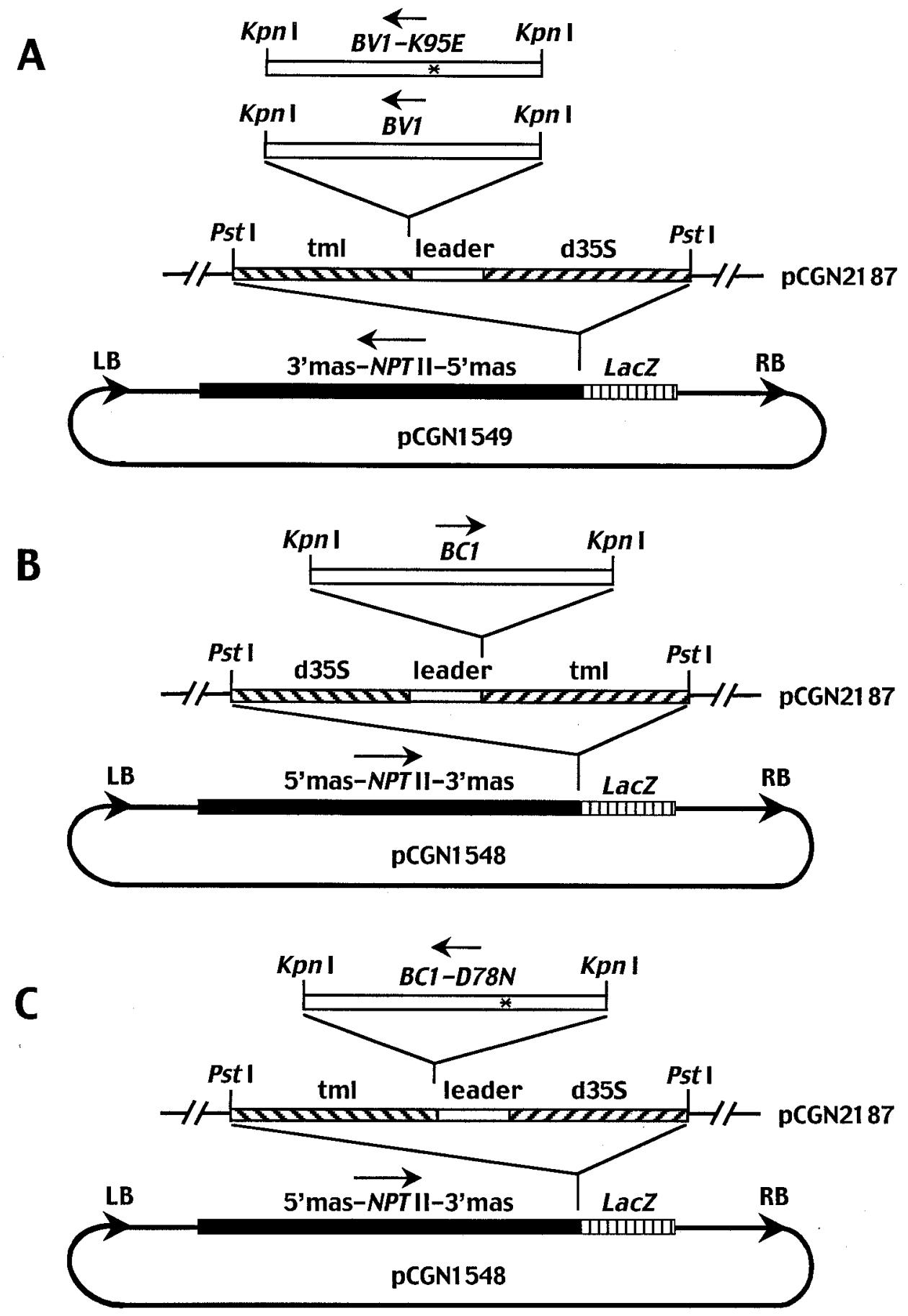

Fig. 1. Expression constructs generated for the wild-type or mutated MP (movement protein) genes of Bean dwarf mosaic virus (BDMV). The (A) BV1, $B V 1-K 95 E$, , B $B C 1$, or (C) BC1-D78N genes were released with KpnI and ligated into pCGN2187 to generate expression cassettes, containing the double $35 \mathrm{~S}$ promoter from Cauliflower mosaic virus (d35S), the leader sequence from Tobacco etch virus (leader), and the polyadenylation signal from the tumor morphology large (tml) region. The expression cassettes were released by digestion with PstI and ligated into the binary vector pCGN1549 for the (A) BV1/BV1-K95E genes or pCGN1548 for the (B) BC1 and (C) BC1-D78N genes. Right (RB) and left borders (LB), $\beta$-galactosidase (LacZ), neomycin phosphotransferase (NPT II), and the MAS promoter and terminator in the binary vectors are noted. The gene orientations are indicated with arrows. Asterisks represent single amino acid substitutions in the mutated MP genes. 
phenotype was similar to that observed in nontransformed tomato plants infected with ToMoV (Fig. 5C). This phenotype, hereafter referred to as the viral disease-like phenotype, was not observed in the BC1-49 plant (Fig. 5B), nor in other transgenic or nontransformed tomato plants (Fig. 5D).

\section{Mapping the deletion of the $B C 1$ gene in the $\mathrm{BC1}-49$ plant.}

The detection of a truncated $\mathrm{BC} 1$ protein and multiple $\mathrm{BC} 1$ transcripts in the $\mathrm{BC} 1-49$ plant suggested that a deletion or rearrangement may have occurred in the $\mathrm{BC} 1$ sequence. To examine this possibility, polymerase chain reaction (PCR) analysis with primers annealing at various positions within the $B C 1$ gene (Fig. 6A) was used to examine total genomic DNA extracted from $\mathrm{BC} 1-49$ and $\mathrm{BC} 1-9 \mathrm{~B}$, a plant expressing the wild-type $\mathrm{BDMV} \mathrm{BC} 1$ protein. When primer PBDBC1c2256, which anneals at the start of the $B C 1$ gene, was paired with primers PBDBC1v1882 and PBDBC1v1582, the expected approximately $0.35-\mathrm{kb}$ and approximately $0.65-\mathrm{kb}$ fragments, respectively, were amplified from the BC1-49 plant (Fig. 6B).

Table 1. Analysis of $R_{0}$ transgenic tomato plants generated with the wild-type or mutant $B V 1$ or $B C 1$ genes of Bean dwarf mosaic virus (BDMV)

\begin{tabular}{lcccc}
\hline Construct & $\begin{array}{c}\text { Regener- } \\
\text { ation fre- } \\
\text { quency }^{\mathbf{a}}\end{array}$ & $\begin{array}{c}\text { MP trans- } \\
\text { gene integra- }^{\text {tion }^{\mathbf{b}}}\end{array}$ & $\begin{array}{c}\text { MP trans- } \\
\text { gene expres- } \\
\text { sion }^{\mathbf{c}}\end{array}$ & $\begin{array}{c}\text { Delayed } \\
\text { ToMoV } \\
\text { infection }^{\mathbf{d}}\end{array}$ \\
\hline BV1 & $5.0 \%$ & $21 / 23(91 \%)$ & $17 / 21(81 \%)$ & 5 \\
BV1-K95E & $14.6 \%$ & $38 / 38(100 \%)$ & $26 / 38(68 \%)$ & 6 \\
BC1 & $4.8 \%$ & $9 / 16(56 \%)$ & $3 / 9(33 \%)$ & 2 \\
BC1-D78N & $2.2 \%$ & $6 / 10(60 \%)$ & $4 / 6(67 \%)$ & 2 \\
\hline
\end{tabular}

a Percentage of shoots regenerated from total cotyledons transformed for three independent experiments.

${ }^{b}$ Number of transgenic plants containing the BDMV MP (movement protein) genes/total number of plants generated.

${ }^{c}$ Number of transgenic plants expressing the BDMV MP/total number of plants containing the MP transgene.

${ }^{\mathrm{d}}$ Plants in which a delay in the onset of Tomato mottle virus (ToMoV) infection, compared with nontransformed control plants, was observed.
However, when PBDBC1c2256 was paired with primers PBDBC1v1504, PBDBC1v1448, PBDBC1v1381, or PBDBC1v1341, no fragments were amplified (Fig. 6B). In contrast, the expected-sized fragments were amplified from the BC1-9B plant with all of these primer combinations (Fig.

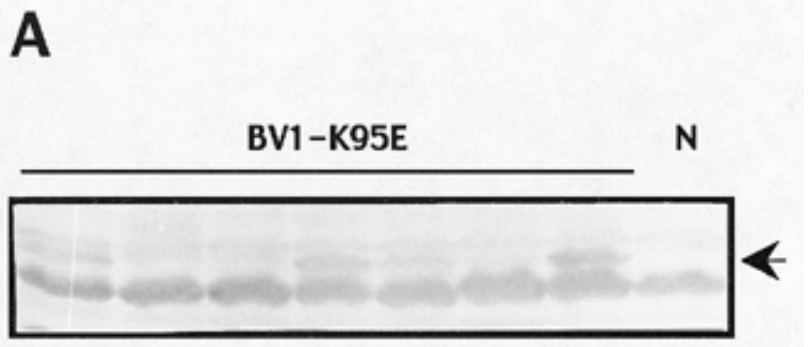

B

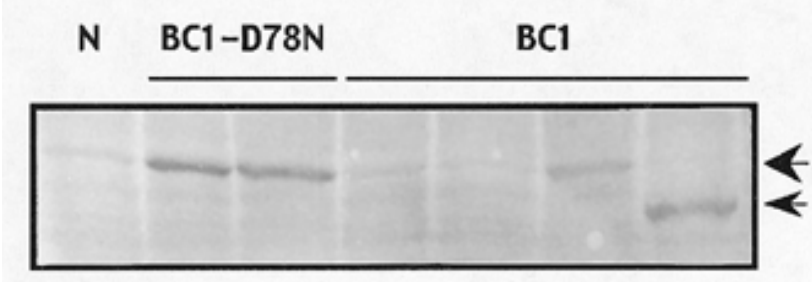

Fig. 3. Immunoblot analysis of $R_{0}$ transgenic tomato plants with the wild-type or mutated MP (movement protein) genes of Bean dwarf mosaic virus (BDMV). Total proteins from (A) BV1-K95E plants were analyzed with BDMV BV1 antisera, and from (B) BC1 or BC1-D78N plants with BDMV BC1 antisera. $\mathrm{N}$ represents a nontransformed tomato plant. Large arrowhead indicates the position of the transgene-encoded protein in (A) lanes 1, 4, 5, and 7, and in (B) lanes 2, 3, and 6. Small arrowhead indicates the truncated $\mathrm{BC} 1$ protein detected in $(\mathbf{B})$ lane 7.

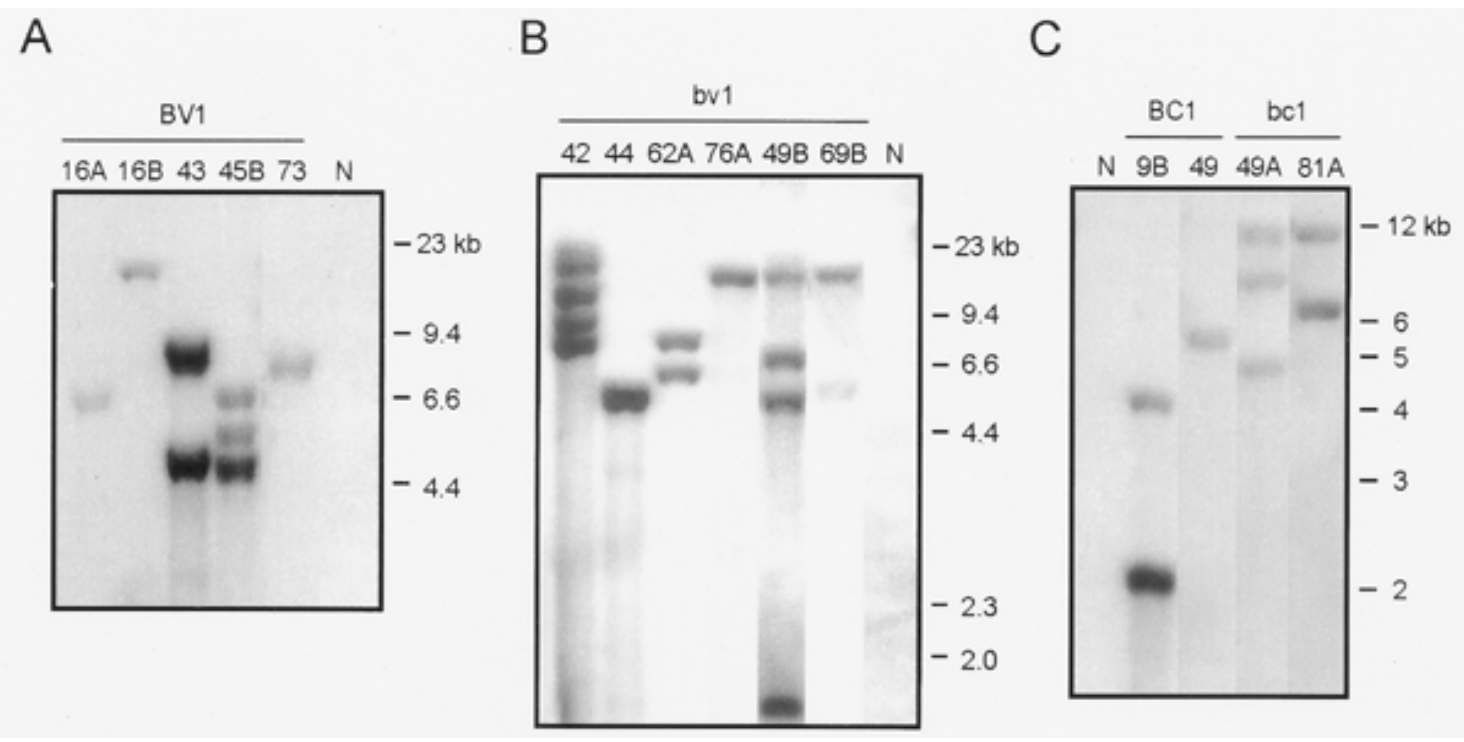

Fig. 2. Southern blot hybridization analysis of $\mathrm{R}_{0}$ transgenic tomato plants with the wild-type or mutated MP (movement protein) genes of Bean dwarf mosaic virus (BDMV). Total genomic DNA from (A) BV1 plants and (B) BV1-K95E plants was hybridized with a BV1-specific probe, and total genomic DNA from $(\mathbf{C}) \mathrm{BC} 1$ and BC1-D78N plants was hybridized with a BC1-specific probe. Numbers represent different plants, and N represents a nontransformed tomato plant. Sizes of DNA markers are indicated (in $\mathrm{kb}$ ). 
6B). When primer PBDBC1c2256 was paired with primer PTML, which anneals within the tumor morphology large (tml) 3' region, the expected approximately $1.2-\mathrm{kb}$ fragment was amplified from the BC1-9B plant, whereas no fragment was amplified from the BC1-49 plant (data not shown). Furthermore, the tml region was not detected in the BC1-49 plant by Southern blot hybridization analysis with a tml-specific probe (data not shown). Together, these results indicated that, in the BC1-49 plant, a deletion had occurred that included approximately 174 nucleotides of the $3^{\prime}$ region of the $B C 1$ gene and the tml region (Fig. 6A).

\section{Infectivity studies with $\mathrm{ToMoV}$ and $\mathrm{R}_{\mathbf{0}}$ plants.}

To determine whether these transgenic plants would be resistant to infection by a geminivirus that is well adapted to tomato, rooted cuttings of $\mathrm{R}_{0}$ plants, having 7 to 10 leaves, were agroinoculated with ToMoV. Inoculated plants were examined for ToMoV infection by PCR analysis at 7- to 10-daypost-inoculation (dpi) intervals, or until plants developed obvious disease symptoms. Results of this infectivity study are summarized in Figure 7A. By 14 dpi, approximately $85 \%$ of nontransformed control plants had developed symptoms typical of ToMoV infection. Plants transformed with the wild-type MP genes had the lowest rates of ToMoV infection at $14 \mathrm{dpi}$, with $52 \%$ of $\mathrm{BV} 1$ and $33 \%$ of $\mathrm{BC} 1$ plants infected. The infection rates for plants expressing mutant BV1 $(61 \%)$ or BC1 $(67 \%)$ proteins were higher than those for plants expressing the wild-type proteins, but still considerably less than those for the nontransformed plants. By $28 \mathrm{dpi}, 100 \%$ of the nontransformed control plants had developed symptoms, whereas approximately $80 \%$ of the transgenic plants, regardless of the transgene, had developed symptoms (Fig. 7A). In all cases, plants showing symptoms (with the exception of $\mathrm{BC} 1$ plants showing the viral disease-like phenotype) were confirmed to be infected by ToMoV based upon PCR amplification of the expected geminivirus fragment; no such fragments were amplified from symptomless plants (data not shown).

Logistic regression analysis of the data in Figure 7A revealed that the transgenic lines, irrespective of the MP gene construct, were significantly different from the nontransformed control in terms of the probability of ToMoV infection. A contrast analysis, comparing probabilities of infection for different BDMV MP constructs, further revealed significant differences between BV1 and BV1-K95E plants and between $\mathrm{BV} 1$ and BV1-K95E versus $\mathrm{BC} 1$ and $\mathrm{BC} 1-\mathrm{D} 78 \mathrm{~N}$ plants.

Two BV1 plants (BV1-16B, BV1-73), 2 BV1-K95E plants (BV1-K95E-44, BV1-K95E-69B), and 1 BC1 plant (BC1-49) did not develop symptoms until $38 \mathrm{dpi}$; and $3 \mathrm{BV} 1$ plants (BV1-16A, BV1-43, BV1-45B), 2 BV1-K95E plants (BV1K95E-49B, BV1-K95E-76A), and 1 BC1 plant (BC1-9B) did not develop symptoms until $50 \mathrm{dpi}$. The greatest delay in the onset of ToMoV infection, $90 \mathrm{dpi}$, was observed for $2 \mathrm{BV} 1$ K95E plants (BV1-K95E-42, BV1-K95E-62A). In general, transgenic plants showing delays in ToMoV infection had low to moderate levels of transgene expression (data not shown). Together, these results indicated that the expression of the BDMV BV1 or BC1 MPs, in wild-type or mutated forms, provided some resistance to infection by ToMoV.

\section{Genetic characterization of $\mathrm{R} 1$ plants.}

Transgenic plants showing delays in the onset of ToMoV infection of $>28$ dpi were selected for further analysis in the $R_{1}$ generation; these plants included BV1-16A, BV1-16B, BV1-43, BV1-45B, BV1-73, BV1-K95E-42, BV1-K95E-44, BV1-K95E-49B, BV1-K95E-62A, BV1-K95E-69B, BV1K95E-76A, BC1-9B, BC1-49, BC1-D78N-49A, and BC1-

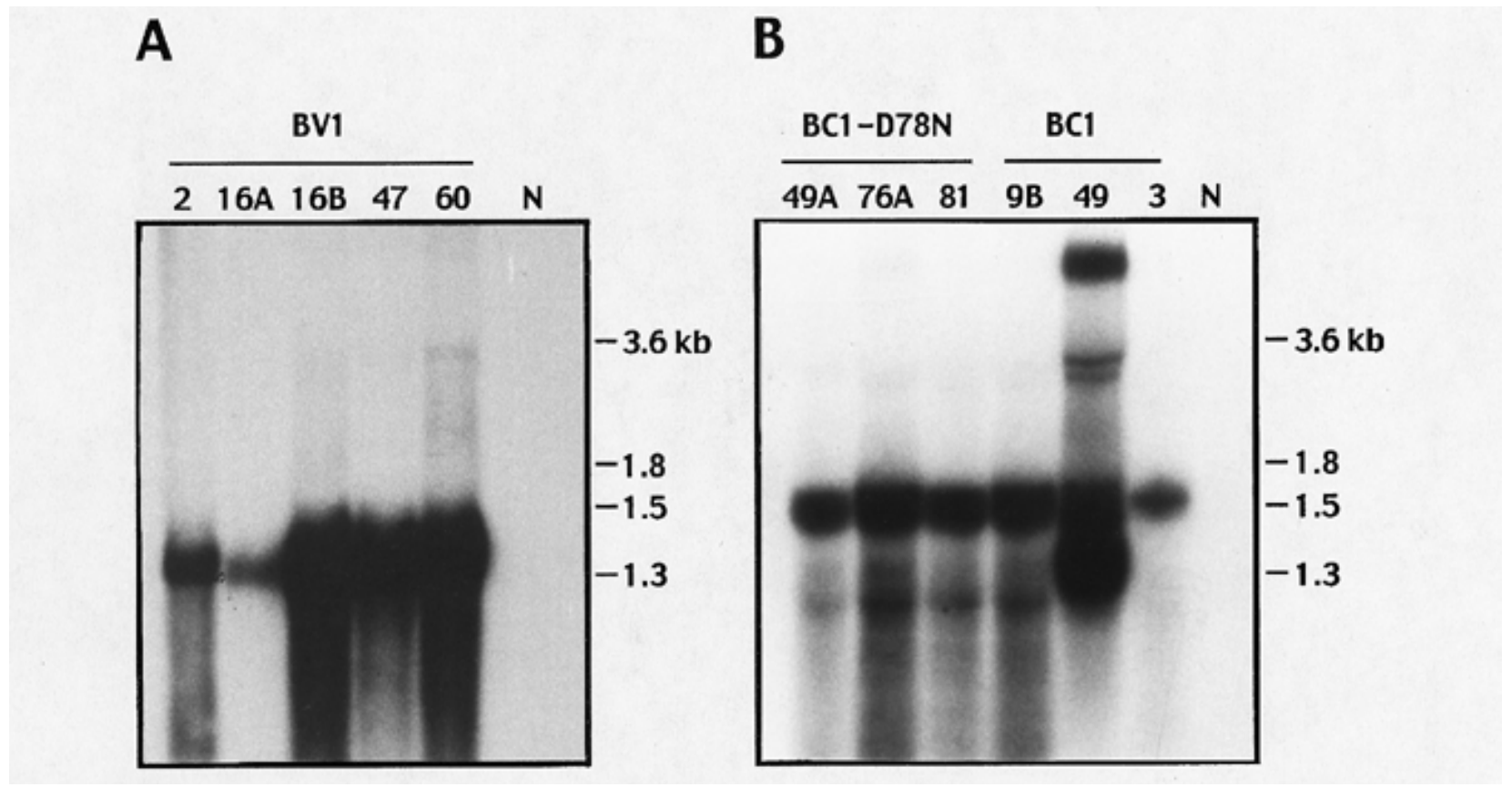

Fig. 4. Northern (RNA) blot hybridization analysis of $\mathrm{R}_{0}$ transgenic tomato plants expressing the wild-type or mutated MP (movement protein) genes of Bean dwarf mosaic virus (BDMV). Total RNA from (A) BV1 plants was hybridized with a BV1-specific probe, and from (B) BC1 or BC1-D78N plants was hybridized with a BC1-specific probe. Numbers represent different plants, and N represents a nontransformed tomato plant. Sizes of RNA markers are indicated (in $\mathrm{kb}$ ). 
D78N-81A. Among these plants, BV1-45B, BV1-73, BV1K95E-42, BV1-K95E-49B, BV1-K95E-62A, and BV1-K95E76A appeared normal, but developed abnormal flowers and failed to produce seeds. Seeds obtained from other self-fertile transgenic plants were screened for a functional NPT II gene by spraying them with kanamycin (Redenbaugh et al. 1992). All $\mathrm{R}_{1}$ seedlings derived from the BV1-16A, BC1-D78N-49A, and $\mathrm{BC} 1-\mathrm{D} 78 \mathrm{~N}-81 \mathrm{~A}$ plants were sensitive to kanamycin. PCR and Southern blot hybridization analyses revealed that neither the $B V 1 / B C 1-D 78 N$ nor the NPT II genes were present in these seedlings (data not shown). Because the transgenes were detected in the $\mathrm{R}_{0}$ plants that produced the seeds from which these $R_{1}$ populations were derived (Fig. 2), these results indicated that the gametes and/or developing embryos were not viable and, thus, were not recovered in the subsequent generation. Alternatively, though less likely, a somatic deletion event may have occurred such that both transgenes were deleted.

Kanamycin-resistant $\mathrm{R}_{1}$ seedlings were obtained for $2 \mathrm{BV} 1$ (BV1-16B, BV1-43), 2 BV1-K95E (BV1-K95E-44, BV1K95E-69B), and 2 BC1 (BC1-9B, BC1-49) plants. The segre-
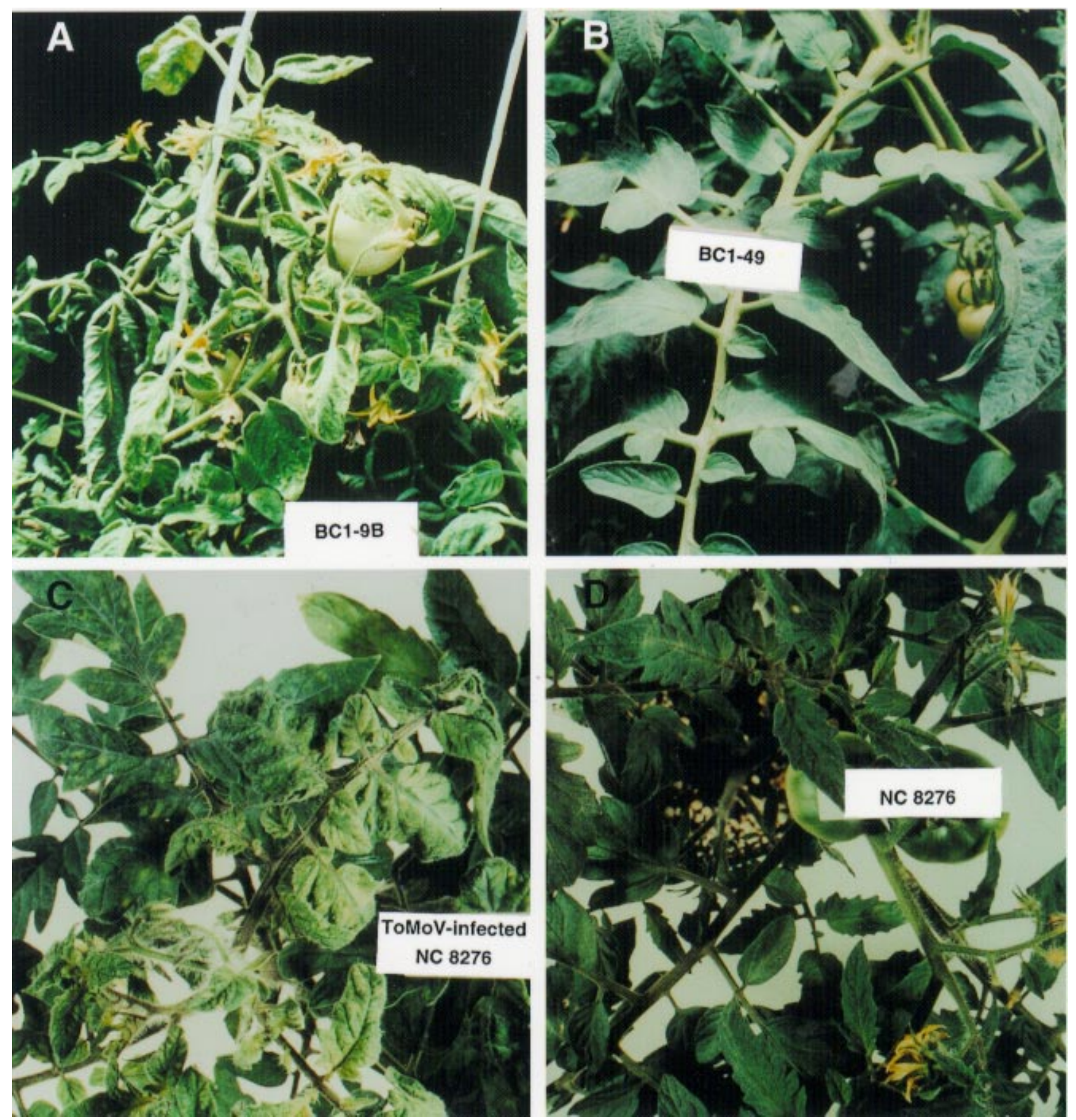

Fig. 5. Phenotypes of transgenic tomato plants expressing (A) the full-length Bean dwarf mosaic virus (BDMV) BC1 protein (represented by the BC19B plant) and (B) the truncated BDMV BC1 protein (the BC1-49 plant). C, A nontransformed tomato plant infected with Tomato mottle virus (ToMoV). D, An uninfected, nontransformed tomato plant. 
gation ratio of kanamycin-resistant to kanamycin-susceptible $\mathrm{R}_{1}$ progeny plants was approximately correlated with the number of integration events that had been previously identified in the $\mathrm{R}_{0}$ plants (Fig. 2 and Table 2); i.e., approximately 15:1 for BV1-43, BV1-K95E-69B, and BC1-9B plants; and approximately 3:1 for BV1-16B, BV1-K95E-44, and BC1-49 plants. Ten kanamycin-resistant seedlings from each of these $\mathrm{R}_{1}$ populations were randomly selected and characterized by Southern blot hybridization and immunoblot analyses. The expected-sized DNA fragments and protein bands were detected in these seedlings (data not shown), indicating normal inheritance and expression of the BDMV MP transgenes.

Infectivity studies with $\mathrm{ToMoV}$ and $\mathrm{R}_{\mathbf{1}}$ plants.

Kanamycin-resistant $\mathrm{R}_{1}$ plants derived from BV1-16B, BV1-43, BV1-K95E-44, BV1-K95E-69B, BC1-9B, and BC1-
49 were agroinoculated with ToMoV (Table 2), and monitored for infection as previously described. Results of this infectivity study are summarized in Figure $7 \mathrm{~B}$. At $14 \mathrm{dpi}, \mathrm{R}_{1}$ plants had lower rates of ToMoV infection (43 to 75\%), compared with nontransformed control plants (approximately 90\%). By $21 \mathrm{dpi}, 100 \%$ of the nontransformed control plants had developed symptoms, whereas 83 to $95 \%$ of BV1 and BV1-K95E $\mathrm{R}_{1}$ plants and $78 \%$ of $\mathrm{BC} 1 \mathrm{R}_{1}$ plants had developed symptoms (Fig. 7B and Table 2). By $35 \mathrm{dpi}$, most $\mathrm{R}_{1}$ plants had developed typical ToMoV symptoms and/or become infected with ToMoV. $\mathrm{R}_{1}$ plants derived from the $\mathrm{BC} 1-9 \mathrm{~B}$ had the lowest rate of infection, but these plants showed the viral disease-like phenotype associated with $\mathrm{BC} 1$ expression.

Logistic regression analysis of the data in Figure 7B again revealed that the transgenic lines, irrespective of the MP gene construct, were significantly different from the nontrans-

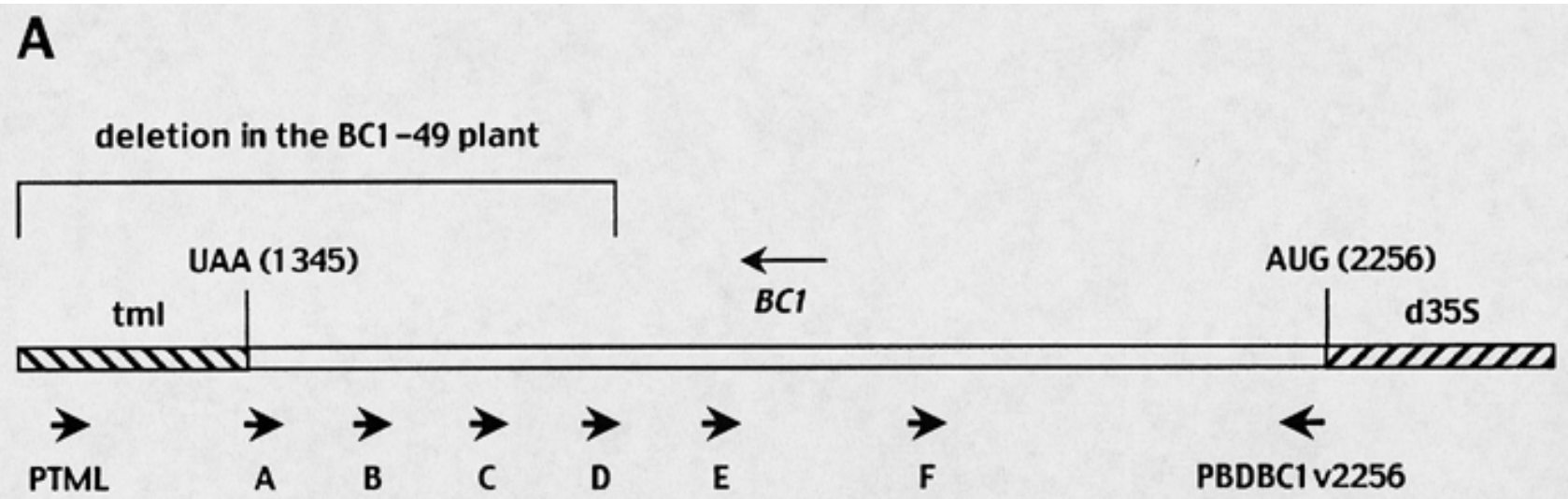

B

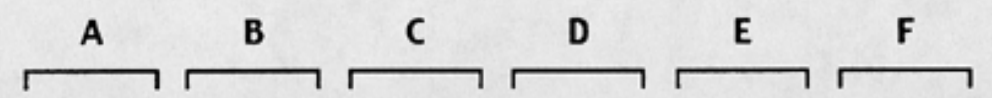

49 9B N 49 9B N 49 9B N 49 9B N 49 9B N 49 9B N

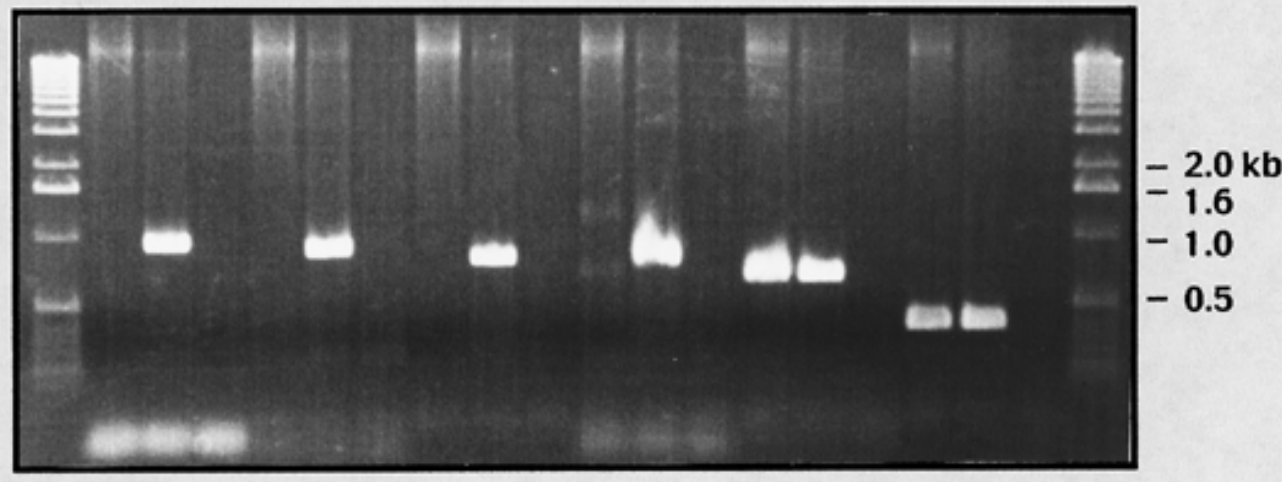

Fig. 6. Mapping the deletion of the $B C 1$ gene in the $\mathrm{BC} 1-49$ plant. A, Polymerase chain reaction (PCR) analysis with primers annealing at different positions within the Bean dwarf mosaic virus (BDMV) $B C 1$ gene. Arrowheads indicate orientations and approximate positions of primers in respect to the $B C 1$ gene in the context of the BDMV DNA-B component. Start codon at nucleotide 2256 and stop codon at nucleotide 1345 of the $B C 1$ gene are indicated in bold. Primers are represented as follows: $\mathrm{A}=$ PBDBC1v1341, $\mathrm{B}=$ PBDBC1v1381, $\mathrm{C}=\mathrm{PBDBC} 1 \mathrm{v} 1448, \mathrm{D}=\mathrm{PBDBC} 1 \mathrm{v} 1504, \mathrm{E}=$ PBDBC1v1582, and F = PBDBC1v1882. B, An ethidium bromide-stained agarose gel showing results of PCR analyses for BC1-9B (9B), BC1-49 (49), and nontransformed (N) plants. Primer pairs are indicated as follows: A, PBDBC1c2256 with PBDBC1v1341; B, PBDBC1c2256 with PBDBC1v1381; C, PBDBC1c2256 with PBDBC1v1448; D, PBDBC1c2256 with PBDBC1v1504; E, PBDBC1c2256 with PBDBC1v1582; and F, PBDBC1c2256 with PBDBC1v1882. Sizes of DNA markers are indicated (in kb). 
formed control in terms of the probability of ToMoV infection. A contrast analysis, comparing probabilities of infection for different BDMV MP constructs, further revealed significant differences between the BV1 and BV1-K95E families, between the $\mathrm{BC} 1$ and $\mathrm{BC} 1-\mathrm{D} 78 \mathrm{~N}$ families, and between the $\mathrm{BV} 1$ and $\mathrm{BV} 1-\mathrm{K} 95 \mathrm{E}$ versus $\mathrm{BC} 1$ and $\mathrm{BC} 1-\mathrm{D} 78 \mathrm{~N}$ families. These results indicated that $\mathrm{R}_{1}$ plants had a significant delay in the onset of ToMoV infection, compared with nontransformed plants; however, the extent of the delay was reduced, compared with that previously observed for the $\mathrm{R}_{0}$ plants (Table 2 ).

\section{DISCUSSION}

Expression of BDMV MPs in transgenic tomato plants has deleterious effects on plant development.

In this study, we analyzed the effect of constitutive expression of the BDMV BV1, BV1-K95E, BC1, or BC1-D78N MPs in tomato, a host that BDMV is not well adapted to (Hou et al. 1998). During the course of these experiments, several observations indicated that expression of BDMV MPs, particularly $\mathrm{BC} 1$ and $\mathrm{BC} 1-\mathrm{D} 78 \mathrm{~N}$, in tomato plants had adverse
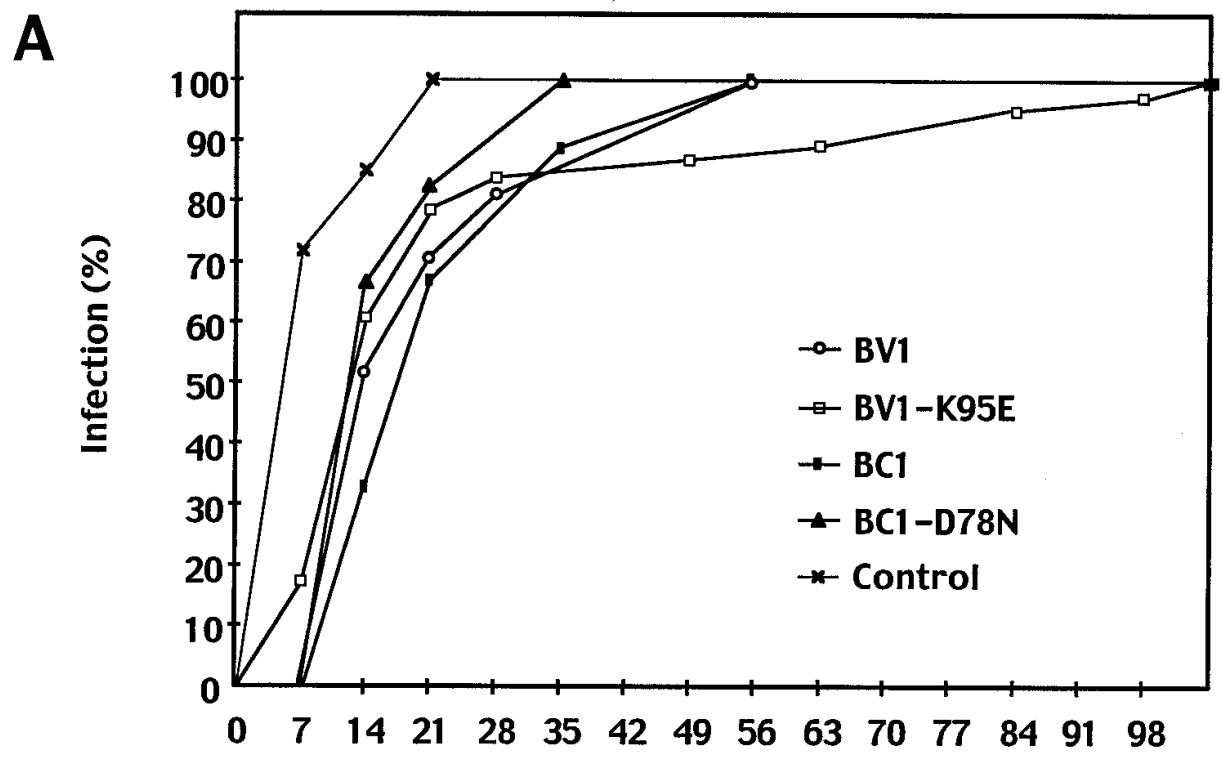

Days post inoculation

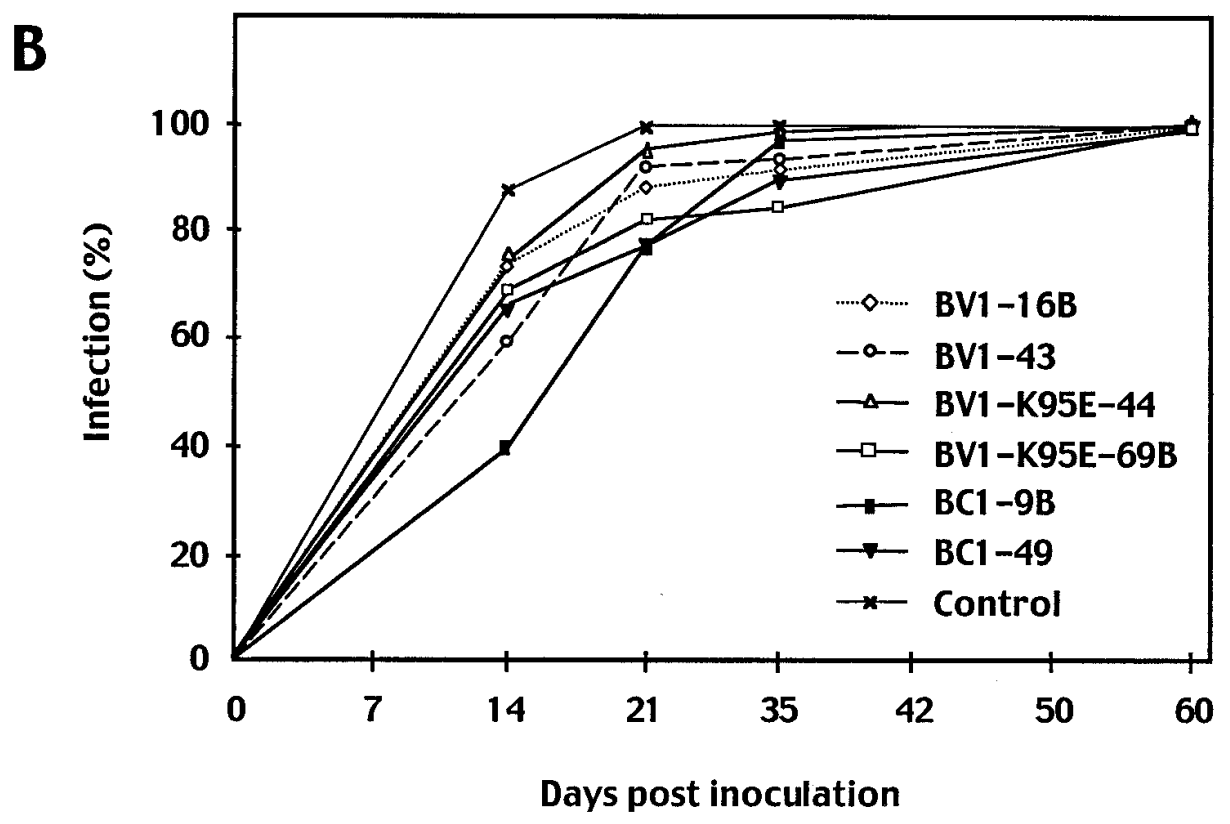

Fig. 7. Results of infectivity studies with Tomato mottle virus (ToMoV) and transgenic tomato plants expressing the wild-type or mutated movement protein genes of Bean dwarf mosaic virus. Rates of ToMoV infection over time are shown for $(\mathbf{A}) \mathrm{R}_{0}$ and $(\mathbf{B}) \mathrm{R}_{1}$ plants. 
effects on various aspects of plant development. First, the regeneration rates (2.2 to $14.6 \%)$ of transformation events with these genes were very low. Second, in several BC1 (44\%) and BC1-D78N (40\%) plants, the MP genes were deleted, whereas the co-transformed NPT II gene was retained. Third, in a number of transgenic plants $(67 \%)$ in which the $B C l$ gene was present, BC1 protein expression was not detected. Fourth, transgenic plants expressing the wild-type size BDMV BC1 protein developed viral disease-like phenotypes. Fifth, several BV1 (40\%) and BV1-K95E (67\%) ToMoV-resistant $\mathrm{R}_{0}$ plants had abnormal flower development and failed to produce seeds. Finally, some BV1 (20\%), and BC1-D78N (100\%) ToMoVresistant $R_{0}$ plants failed to transmit the transgene to $R_{1}$ progeny. Together, these results indicate that neither the wild-type nor mutated BDMV MPs are well tolerated in regenerated tissues and/or during production of gametes or embryos. This presumably is a function of these proteins being involved in viral pathogenicity.

Transgenic tomato plants expressing the BDMV BV1 or BV1-K95E proteins appeared normal, which is in agreement with reports for transgenic $N$. benthamiana plants expressing the Squash leaf curl virus (SqLCV) BV1 protein (Pascal et al. 1993) and $N$. tabacum plants expressing the ToMoV BV1 protein (Duan et al. 1997b). However, for several BV1 and BV1-K95E plants, flower development was abnormal and no seeds were recovered. This is in contrast to normal fertility reported for transgenic $N$. benthamiana plants expressing the SqLCV BV1 protein (Pascal et al. 1993). Expression of the BDMV BV1 or BV1-K95E proteins in tomato plants, particularly in the reproductive tissues, may cause a reduction in fertility. Because this was observed for transgenic plants expressing either the BV1 or BV1-K95E proteins, the reduced fertility may be independent of the nuclear transport function of the BV1 protein.

\section{The BDMV BC1 protein is a symptom determinant in a nonhost plant.}

The development of the viral disease-like phenotype in plants expressing the BDMV $\mathrm{BC} 1$ protein is consistent with previous studies indicating that the $\mathrm{BC} 1$ is a symptom determinant for bipartite geminiviruses (von Arnim and Stanley

Table 2. Results of infectivity studies with Tomato mottle virus (ToMoV) and $\mathrm{R}_{0}$ and $\mathrm{R}_{1}$ transgenic tomato plants expressing the wildtype or mutant $B V 1$ or BCl genes of Bean dwarf mosaic virus (BDMV)

\begin{tabular}{|c|c|c|c|c|}
\hline Plant & $\begin{array}{c}\text { Trans- } \\
\text { gene } \\
\text { copy }^{\text {a }}\end{array}$ & $\begin{array}{l}\text { ToMoV in- } \\
\text { fection in } \\
\mathbf{R}_{\mathbf{0}} \text { plants }^{\mathbf{b}}\end{array}$ & $\begin{array}{c}\text { No. of } R_{1} \\
\text { plants in- } \\
\text { oculated }\end{array}$ & $\begin{array}{c}R_{1} \text { plants } \\
\text { infected at } \\
21 \text { dpi }^{\mathbf{c}}\end{array}$ \\
\hline BV1-16B & 1 & 38 days & 35 & $31(89 \%)$ \\
\hline BV1-43 & 2 & 51 days & 30 & $28(93 \%)$ \\
\hline BV1-K95E-44 & 1 & 38 days & 85 & $81(95 \%)$ \\
\hline BV1-K95E-69B & 2 & 38 days & 52 & $43(83 \%)$ \\
\hline BC1-9B & 2 & 56 days & 40 & $31(78 \%)$ \\
\hline BC $1-49$ & 1 & 38 days & 36 & $28(78 \%)$ \\
\hline Control & $\mathrm{NA}^{\mathrm{d}}$ & 14 days & 25 & $25(100 \%)$ \\
\hline
\end{tabular}

a Transgene copy number was determined based on Southern blot hybridization analysis with BV1- or BC1-specific probes.

${ }^{b}$ Onset of ToMoV infection in the $\mathrm{R}_{0}$ parent as determined by development of symptoms and polymerase chain reaction (PCR) analysis.

${ }^{c}$ Number of plants infected at 21 dpi (days post inoculation) as determined by development of symptoms and PCR analysis.

d Not applicable.
1992; Ingham et al. 1995). Viral disease-like phenotypes have also been described in transgenic $N$. benthamiana plants expressing the SqLCV BC1 protein (Pascal et al. 1993) and transgenic $N$. tabacum plants expressing the ToMoV BC1 protein (Duan et al. 1997a). This phenomenon has also been reported for transgenic $N$. tabacum plants expressing the $\mathrm{C} 4$ protein of the monopartite geminiviruses Tomato leaf curl virus (Krake et al. 1998) or Beet curly top virus (genus Curtovirus; Latham et al. 1997). Results of the present study extend upon these reports in that expression of the BDMV $\mathrm{BC} 1$ protein in tomato, which is essentially a nonhost of the virus, led to the development of the viral disease-like phenotype. This suggests that the BDMV $\mathrm{BC} 1$ protein is functional in tomato plants and, thus, that the inability of BDMV to efficiently infect and induce symptoms in tomato is not due to a nonfunctional BC1 MP, but to other viral and/or host factors.

The viral disease-like phenotype may be associated with, at least in part, the interference of the BDMV BC1 MP with normal macromolecular trafficking (Lucas et al. 1995). This has been suggested for transgenic $N$. tabacum plants expressing the 30-kDa MP of Tobacco mosaic virus (TMV; Lucas et al. 1993, 1996), or the 17-kDa MP of Potato leafroll virus (Herbers et al. 1997). These transgenic plants have abnormal phenotypes, such as chlorosis and stunted growth, as well as an altered plasmodesmal structure and/or size exclusion limit. In the case of the BDMV BC1 protein, this hypothesis is supported by the normal phenotype observed in transgenic plants expressing the $\mathrm{BC} 1-\mathrm{D} 78 \mathrm{~N}$ protein, which failed to increase the size exclusion limit of plasmodesmata in microinjection studies (Noueiry et al. 1994). However, expression of the BC1-D78N protein still had deleterious effects on plant development based upon the low regeneration rate of BC1-D78N plants (lowest rate of all four MP transgenes), and the inability to recover $\mathrm{R}_{1}$ plants expressing this protein. Together, these results indicate that the constitutive expression of functional viral MPs, with the capability of modifying the size exclusion limit of plasmodesmata, has adverse effects on plant development.

The normal phenotype in the BC1-49 plant was associated with a deletion in the $3^{\prime}$ region of the $B C 1$ gene. Similar results have been reported for transgenic $N$. benthamiana plants expressing the N-terminal 193 amino acids of the SqLCV BC1 protein (Pascal et al. 1993), and for transgenic N. tabacum plants expressing a truncated ToMoV BC1 protein (Duan et al. 1997a). This suggests that the C-terminal region of the $\mathrm{BC} 1$ protein contains a domain(s) responsible for symptom development. These deletion mutants may have lost their ability to interact with and/or increase the size exclusion limit of plasmodesmata. Microinjection studies with these deleted $\mathrm{BC} 1 \mathrm{MPs}$ or in transgenic plants expressing wild-type versus mutated BC1 MPs, would establish whether there is a correlation between the cell-to-cell transport function of the $\mathrm{BC} 1$ protein and symptom development.

In a study by Duan et al. (1997a), a spontaneous deletion in the 3 ' region of the ToMoV BCl transgene also occurred during the transformation process. Transgenic $N$. tabacum plants expressing this truncated $\mathrm{ToMoV} \mathrm{BC} 1$ protein showed varying degrees of resistance to infection by ToMoV and Cabbage leaf curl virus. In the present study, the BC1-49 plant showed a delay in the onset of ToMoV infection, but not the high levels of resistance reported by Duan et al. (1997b). In both cases, 
the transgene was introduced into a plant species that is not the natural host of the virus (i.e., that the virus is not well adapted to). However, an experimental host of ToMoV ( $N$. tabacum) was transformed in the study by Duan et al. (1997b), whereas the natural host of ToMoV (tomato) was transformed in the present study. Begomoviruses generally have low rates of infection and induce mild or attenuated symptoms in hosts to which they are not adapted (Hou et al. 1998). This may have contributed to the high levels of resistance to geminivirus infection observed in transgenic $N$. tabacum plants by Duan et al. (1997b). Alternatively, differences in the source of the transgenes (i.e., ToMoV versus BDMV BC1) and/or differences in the transgene deletion and, thus, the corresponding transgene products could explain the higher levels of resistance. In the study by Duan et al. (1997a), the C-terminal deletion in the ToMoV BCl gene was 119 amino acids (357 nucleotides) and, together with an additional 26 amino acids derived from an unidentified source, resulted in the expression of an approximately $23-\mathrm{kDa}$ protein. In the present study, the C-terminal deletion in the BDMV $B C 1$ gene in the BC1-49 plant was approximately 58 amino acids (approximately 174 nucleotides), which resulted in expression of an approximately 31-kDa protein. Differences in the properties of the two truncated $\mathrm{BC} 1$ proteins may have influenced the level of geminivirus resistance in plants transformed with these transgenes. Finally, different inoculation methods were utilized in these two studies; Duan et al. (1997b) inoculated plants with whiteflies, whereas agroinoculation was used in the present study. Agroinoculation may deliver more viral inoculum over a longer period of time, possibly overcoming low or moderate levels of resistance.

\section{MP genes as a source of pathogen-derived resistance for geminivirus infection.}

$\mathrm{R}_{0}$ plants, each having one of the four MP gene constructs, had significant delays in the onset of ToMoV infection, compared with nontransformed control plants. These results indicate that both wild-type and mutated BDMV BV1 and BC1 MPs can act as dominant negative mutants and provide resistance against a different (though related) geminivirus. Interestingly, plants expressing the functional BDMV BV1 or BC1 MPs had higher levels of resistance than plants expressing the mutated MPs. In contrast, transgenic tobacco plants expressing either the functional 30-kDa MP of TMV (Cooper et al. 1995) or ToMoV BV1 or BC1 MPs (Duan et al. 1997b) did not show resistance to TMV and ToMoV, respectively. During the life cycle of bipartite geminiviruses, BV1 and, possibly, $\mathrm{BC} 1$, are expressed later than genes involved in replication (Haley et al. 1992; Sunter and Bisaro 1992). It is possible that constitutive expression of the BDMV BV1 or BC1 MPs results in binding and/or in the premature transport of incoming ToMoV DNA, either out of the nucleus (BV1) or the cell (BC1). This would interfere with normal viral DNA replication. This perturbation of the viral life cycle may be responsible for the resistance observed in the $\mathrm{BV} 1$ and $\mathrm{BC} 1$ transgenic plants.

The $R_{1}$ progeny of these transgenic plants did not show similar delays in infection, compared with their $R_{0}$ parent plants. The differences in levels of ToMoV resistance between $\mathrm{R}_{0}$ and $\mathrm{R}_{1}$ plants may be due to the developmental stage at which plants were inoculated. The inoculated $R_{0}$ plants were rooted cuttings of primary transformants (equivalent to 2- to 3-month-old plants), whereas the inoculated $\mathrm{R}_{1}$ plants were 4 to 6-week-old seedlings. The delayed infection observed in $\mathrm{R}_{0}$ plants may have been a combined effect of the MP gene and the age of plants (older plants tend to be more resistant to geminivirus infection).

In conclusion, while the resistance in transgenic tomato plants expressing the wild-type or mutated BDMV MPs was manifested as a delay in the onset of ToMoV infection, our results and those of Duan et al. (1997b) suggest that expression of geminiviral MPs in transgenic plants can provide some level of resistance to viral infection. Further studies involving transgenic plants expressing different MP constructs (e.g., various truncated forms) appear warranted.

\section{MATERIALS AND METHODS}

Plasmid constructions and plant transformation.

DNA manipulations were performed according to standard protocols (Ausubel et al. 1994). The wild-type BDMV MP genes were amplified from DNA extracted from BDMVinfected plants and the mutated BDMV $B V 1$ and $B C 1$ genes were amplified from pBV1-Lys-95 and pBC1-Asp-78 (Noueiry et al. 1994), respectively. The BV1 genes were amplified with primers PBDBV1v534 (5'-TACGATCGGTACC TAATAATGGATGGT-3') and PBDBV1c1338 (5'-CCGTTT GGTACCATTACCATTAATCAACC-3'), and the $B C 1$ genes were amplified with primers PBDBC1c2256 (5'-CGCGGCC GGTACCTTAATATGGATTCTC-3') and PBDBC1v1341 (5'TTGCGAGGTACCGCTATTATTGAACT-3'); underlined sequences represent $K p n I$ sites and initiation codons are shown in italics.

The PCR-amplified fragments were digested with KpnI and individually ligated into $\mathrm{pKS}+$ (Stratagene, La Jolla, CA) to generate pBDBV1, pBDBV1-K95E, pBDBC1, and pBDBC1$\mathrm{D} 78 \mathrm{~N}$. The genes were sequenced, released by digestion with $K p n I$, and individually ligated into the intermediate vector pCGN2187 (C. Shewmaker, personal communication). Expression cassettes were released by digestion with PstI, and individually ligated into pCGN1549 (for the $B V I$ and $B V I$ $K 95 E$ genes) or pCGN1548 (for the $B C 1$ and $B C 1-D 78 N$ genes) to generate pTBDBV1, pTBDBV1-K95E, pTBDBC1, and pTBDBC1-D78N, respectively (Fig. 1). Recombinant binary plasmids were introduced into Agrobacterium tumefaciens LBA4404 by the freeze/thaw method (Hou et al. 1998). Agrobacterium-mediated transformation of Lycopersicon esculentum cv. NC8276 was performed as previously described (Fillatti et al. 1987).

\section{ToMoV inoculation, and analyses of infected plants and infectivity data.}

Tomato plants were agroinoculated with ToMoV by the needle puncture method (Hou et al. 1998). Inoculated plants were maintained in a growth chamber $\left(250 \mu \mathrm{mol} \mathrm{s} \mathrm{s}^{-1} \mathrm{~m}^{-2}\right.$ photosynthetically active radiation $16 \mathrm{~h}$ per day, $30^{\circ} \mathrm{C}$ ). Symptoms were recorded at various intervals and ToMoV infection was confirmed in all plants by PCR analysis. DNA extraction, degenerate primers, and PCR conditions have been previously described (Hou and Gilbertson 1996). Infectivity data were analyzed by logistic regression by the catmod (categorical models) procedure of SAS (SAS Institute, Cary, NC). 
DNA extraction, Southern blot hybridization analysis, and mapping the $\mathrm{BC} 1$ deletion in the $\mathrm{BC1}-49$ plant.

Approximately $0.2 \mathrm{~g}$ of leaf tissue was ground in $0.5 \mathrm{ml}$ of extraction buffer $(0.35 \mathrm{M}$ sorbitol, $0.1 \mathrm{M}$ Tris, $5 \mathrm{mM}$ EDTA, and $0.38 \%$ sodium bisulfite, $\mathrm{pH} 7.5$ ), and centrifuged at $10,000 \times g$ for $5 \mathrm{~min}$. The resulting pellet was homogenized in $0.2 \mathrm{ml}$ of extraction buffer and $0.2 \mathrm{ml}$ of lysis buffer $(0.2 \mathrm{M}$ Tris, $50 \mathrm{mM}$ EDTA, $2 \mathrm{M} \mathrm{NaCl}$, and 2\% CTAB, pH 7.5) containing $0.5 \%$ Sarkosyl, incubated at $65^{\circ} \mathrm{C}$ for $30 \mathrm{~min}$, and extracted with an equal volume of chloroform/isoamyl alcohol. Total nucleic acids were precipitated with isopropanol and recovered by centrifugation at $10,000 \times g$ for $10 \mathrm{~min}$.

Approximately $15 \mu \mathrm{g}$ of genomic DNA was digested with $X b a \mathrm{I}$ (R0 plants) or double-digested with KpnI and HindIII ( $\mathrm{R}_{1}$ plants), fractionated in $0.8 \%$ agarose gels in Tris-borate-EDTA buffer, and transferred to Hybond N+ membrane (Amersham, Arlington Heights, IL). Blots were hybridized with probes labeled with $\left[\alpha-{ }^{32} \mathrm{P}\right] \mathrm{dCTP}$ by random priming according to the manufacturer's instructions (Ambion, Austin, TX).

The deletion in the $B C l$ gene was mapped by PCR analysis (Fig. 6). Primers used to analyze the deletion in the $B C l$ gene were PBDBC1v1882 (5'-TATCGCAAACCCTATAATAGAG TT-3'), PBDBC1v1582 (5'-CCACCTCTGAGTCGGCATCG GAGT-3'), PBDBC1v1504 (5'-CAATTGAGGCAGACTC$\left.3^{\prime}\right)$, PBDBC1v1448 (5'-CTCGTTTAATTGCCCC-3'), and PBDBC1v1381 (5'-GCAACGATTTGGGCTG-3'), and PTML (5'-CCGAATCGATGACACTCTCTTGGTTCC-3').

\section{RNA extraction and Northern blot analysis.}

Total RNA was extracted from leaf tissue according to the manufacturer's instructions (Qiagen, Chatsworth, CA). Approximately $15 \mu \mathrm{g}$ of total RNA was fractionated in 1.4\% agarose gels containing formaldehyde (Ausubel et al. 1994), and transferred to Nytran membrane (Schleicher \& Schuell, Keene, NH). Blots were hybridized with probes labeled with $\left[\alpha-{ }^{32} \mathrm{P}\right] \mathrm{dCTP}$ by random priming according to the manufacturer's instructions (Ambion, Austin, TX).

\section{Protein extraction and Western blot (immunoblot) analysis.}

Approximately $0.25 \mathrm{~g}$ of young leaf tissue was ground in $0.5 \mathrm{ml}$ of grinding buffer $(0.125 \mathrm{M}$ Tris, $\mathrm{pH} 6.8,20 \%$ glycerol, $1 \%$ SDS [sodium dodecyl sulfate], $5 \% \quad \beta$-mercaptoethanol, and $2.5 \%$ bromophenol blue), boiled for $5 \mathrm{~min}$, and centrifuged at $10,000 \times g$ for $5 \mathrm{~min}$. Ten microliters of total protein was fractionated in $12 \%$ SDS-polyacrylamide gel electrophoresis gels in Tris-glycine buffer with $0.1 \%$ SDS, and blotted to PVDF (polyvinyldifluoride) membrane (Millipore, Bedford, MA). Blots were incubated with rabbit polyclonal antisera in TBST (10 mM Tris, pH 8.0, 0.25 M NaCl, and 0.5\% Tween 20) and substrate solution according to the manufacturer's instructions (Promega, Madison, WI).

\section{ACKNOWLEDGMENTS}

We thank Maureen Daly for assistance in tissue culture, Kate McGuire for maintaining transgenic plants, and M. R. Sudarshana for the BDMV BV1 and BC1 antisera. This work was supported in part by fellowships from the College of Agricultural and Environmental Sciences, University of California-Davis to Y.-M. H., and by a grant from the United States Department of Agriculture National Research Initiative Competitive Grants Program (9301256) to R. L. G.

\section{LITERATURE CITED}

Ares, X., Calamante, G., Cabral, S., Lodge, J., Hemenway, P., Beachy, R. N., and Mentaberry, A. 1998. Transgenic plants expressing potato virus X ORF2 protein (p24) are resistant to tobacco mosaic virus and Ob tobamoviruses. J. Virol. 72:731-738.

Ausubel, F. M., Brent, R., Kingston, R. E., Moore, D. D., Seidman, J. G., Smith, J. A., and Struhl, K. 1994. Current Protocols in Molecular Biology. John Wiley \& Sons, New York.

Beck, D. L., VanDolleweerd, C. J., Lough, T. J., Balmori, E., Voot, D. M., Andersen, M. T., O'Brien, I. E. W., and Forster, R. L. S. 1994. Disruption of virus movement confers broad-spectrum resistance against systemic infection by plant viruses with a triple gene block. Proc. Natl. Acad. Sci. USA 91:10310-10314.

Bejarano, E. R., and Lichtenstein, C. P. 1994. Expression of TGMV antisense RNA in transgenic tobacco inhibits replication of BCTV but not ACMV geminiviruses. Plant Mol. Biol. 24:241-248.

Bendahmane, M., and Gronenborn, B. 1997. Engineering resistance against tomato yellow leaf curl virus (TYLCV) using antisense RNA. Plant Mol. Biol. 33:351-357.

Bock, K. R. 1982. Geminivirus diseases in tropical plants. Plant Dis. 66: 266-270.

Brown, J. K. 1990. An update of the whitefly-transmitted geminiviruses in the Americas and the Caribbean Basin. FAO Plant Prot. Bull. 39:523.

Cooper, B., Lapidot, M., Heick, J. A., Dodds, J. A., and Beachy, R. N. 1995. A defective movement protein of TMV in transgenic plants confers resistance to multiple viruses whereas the functional analog increases susceptibility. Virology 206:307-313.

Day, A. G., Bejarano, E. R., Buck, K. W., Burrell, M., and Lichtenstein, C. P. 1991. Expression of an antisense viral gene in transgenic tobacco confers resistance to the DNA virus tomato golden mosaic virus. Proc. Natl. Acad. Sci. USA 88:6721-6725.

Duan, Y.-P., Powell, C. A., Purcifull, D. E., Broglio, P., and Hiebert, E. 1997a. Phenotypic variation in transgenic tobacco expressing mutated geminivirus movement/pathogenicity (BC1) proteins. Mol. PlantMicrobe Interact. 10:1065-1074.

Duan, Y.-P., Powell, C. A., Webb, S. E., Purcifull, D. E., and Hiebert, E. 1997b. Geminivirus resistance in transgenic tobacco expressing mutated BC1 protein. Mol. Plant-Microbe Interact. 10:617-623.

Fillatti, J. J., Kiser, J., Rose, R., and Comai, L. 1987. Efficient transfer of a glyphosate tolerance gene into tomato using a binary Agrobacterium tumefaciens vector. Bio/Technology 5:726-730.

Gilbertson, R. L., Hidayat, S. H., Paplomatas, E. J., Rojas, M. R., Hou, Y.-M., and Maxwell, D. P. 1993. Pseudorecombination between infectious cloned DNA components of tomato mottle and bean dwarf mosaic geminiviruses. J. Gen. Virol. 74:23-31.

Haley, A., Zhan, B., Richardson, K., Head, K., and Morris, B. 1992. Regulation of the activities of African cassava mosaic virus promoters by the AC1, AC2, and AC3 gene products. Virology 188:905-909.

Herbers, K., Tacke, E., Hazirezaei, M., Krause, K.-P., Melzer, M., Rohde, W., and Sonnewald, U. 1997. Expression of a luteoviral movement protein in transgenic plants leads to carbohydrate accumulation and reduced photosynthetic capacity in source leaves. Plant J. 12:10451056.

Hong, Y., and Stanley, J. 1996. Virus resistance in Nicotiana benthamiana conferred by African cassava mosaic virus replication-associated protein (AC1) transgene. Mol. Plant-Microbe Interact. 9:219-225.

Hou, Y.-M., and Gilbertson, R. L. 1996. Increased pathogenicity in a pseudorecombinant bipartite geminivirus correlates with intermolecular recombination. J. Virol. 70:5430-5436.

Hou, Y.-M., Paplomatas, E. J., and Gilbertson, R. L. 1998. Host adaptation and replication properties of two bipartite geminiviruses and their pseudorecombinants. Mol. Plant-Microbe Interact. 11:208-217.

Ingham, D. J., Pascal, E., and Lazarowitz, S. G. 1995. Both bipartite geminivirus movement proteins define viral host range, but only BL1 determines viral pathogenicity. Virology 207:191-204.

Krake, L. R., Rezaian, M. A., and Dry, I. B. 1998. Expression of tomato leaf curl geminivirus $C 4$ gene produces viruslike symptoms in transgenic plants. Mol. Plant-Microbe Interact. 11:413-417.

Kunik, T., Salomon, R., Zamir, D., Navot, N., Zeidan, M., Michelson, I., Gafni, Y., and Czosnek, H. 1994. Transgenic tomato plants expressing the tomato yellow leaf curl virus capsid protein are resistant to the virus. Bio/Technology 12:500-504. 
Latham, J. R., Saunders, K., Pinner, M. S., and Stanley, J. 1997. Induction of plant cell division by beet curly top virus gene C4. Plant J. 11:1273-1283.

Lucas, W. J., Balachandran, S., Park, J., and Wolf, S. 1996. Plasmodesmal companion cell-mesophyll communication in the control over carbon metabolism and phloem transport: insights gained from viral movement proteins. J. Exp. Bot. 47:1119-1128.

Lucas, W. J., Bouche-Pillon, S., Jackson, D. P., Nguyen, L., Baker, L., Ding, B., and Hake, S. 1995. Selective trafficking of KNOTTED1 homeodomain protein and its mRNA through plasmodesmata. Science 270:1980-1983.

Lucas, W. J., Olesinski, A., Hull, R. J., Haudenshield, J. S., Deom, C. M., Beachy, R. N., and Wolf, S. 1993. Influence of the tobacco mosaic virus $30 \mathrm{kDa}$ protein on carbon metabolism and photosynthate partitioning in transgenic tobacco plants. Planta 190:88-96.

Malyshenko, S. I., Kondakova, O. A., Nazarova, J. V., Kaplan, I. B., Taliansky, M. E., and Atabekov, J. G. 1993. Reduction of tobacco mosaic virus accumulation in transgenic plants producing non-functional viral transport proteins. J. Gen. Virol. 74:1149-1156.

Noris, E., Accotto, G. P., Tavazza, R., Brunetti, A., Crespi, S., and Tavazza, M. 1996. Resistance to tomato yellow leaf curl geminivirus in Nicotiana benthamiana plants transformed with a truncated viral C1 gene. Virology 224:130-138.

Noueiry, A. O. 1995. Molecular and biochemical analysis of mechanisms involved in the movement of a bipartite geminivirus in plants. $\mathrm{Ph} . \mathrm{D}$. thesis. University of California, Davis.

Noueiry, A. O., Lucas, W. J., and Gilbertson, R. L. 1994. Two proteins of a plant DNA virus coordinate nuclear and plasmodesmal transport. Cell 76:925-932.

Pascal, E., Goodlove, P. E., Wu, L. C., and Lazarowitz, S. G. 1993. Transgenic tobacco plants expressing the geminivirus BL1 protein exhibit symptoms of viral disease. Plant Cell 5:795-807.

Polston, J. E., and Anderson, P. K. 1997. The emergence of whiteflytransmitted geminiviruses in tomato in the Western Hemisphere. Plant Dis. 81:1358-1369.

Redenbaugh, K., Hiatt, W., Martineau, B., Kramer, M., Sheehy, R.,
Sanders, R., Houck, C., and Emlay, D. 1992. Safety assessment of genetically engineered fruits and vegetables: A case study of the Flavr Savr tomato. CRC Press, Boca Raton, FL.

Rojas, M. R., Noueiry, A. O., Lucas, W. J., and Gilbertson, R. L. 1998. Bean dwarf mosaic geminivirus movement proteins recognize DNA in a form- and size-specific manner. Cell 95:105-113.

Sanford, J. C., and Johnston, S. A. 1985. The concept of parasite-derived resistance - deriving resistance genes from the parasites' own genome. J. Theor. Biol. 113:395-405.

Sangare, A., Deng, D., Fauquet, C. M., and Beachy, R. N. 1999. Resistance to African cassava mosaic virus conferred by a mutant of the putative NTP-binding domain of the Rep gene (AC1) in Nicotiana benthamiana. Mol. Biol. Rep. 5:95-102.

Seppanen, P., Puska, R., Honkanen, J., Tyulkina, L. G., Fedorkin, O., Morozov, S. Y., and Atabekov, J. G. 1997. Movement protein-derived resistance to triple gene block-containing plant viruses. J. Gen. Virol. 78:1241-1246.

Sharp, L. P., Hou, Y. M., Garrido-Ramirez, E. R., Guzman, P., and Gilbertson, R. L. 1999. Characterization of a new geminivirus DNA-A component from tomatoes with chino del tomate disease. Phytopathology 88:S81.

Stanley, J., Frischmuth, T., and Ellwood, S. 1990. Defective viral DNA ameliorates symptoms of geminivirus infection in transgenic plants. Proc. Natl. Acad. Sci. USA 87:6291-6295.

Sunter, G., and Bisaro, D. M. 1992. Transactivation of geminivirus AR1 and BR1 gene expression by the viral AL2 gene product occurs at the level of transcription. Plant Cell 4:1321-1331.

Tacke, E., Salamini, F., and Rohde, W. 1996. Genetic engineering of potato for broad-spectrum protection against virus infection. Nature Biotechnol. 14:1597-1601.

Timmermans, M. C. P., Das, O. P., and Messing, J. 1994. Geminiviruses and their uses as extrachromosomal replicons. Annu. Rev. Plant Physiol. Plant Mol. Biol. 45:79-112.

von Arnim, A., and Stanley, J. 1992. Inhibition of African cassava mosaic virus systemic infection by a movement protein from the related geminivirus tomato golden mosaic virus. Virology 187:555-564. 